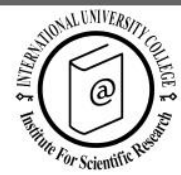

\title{
Revisiting the role of incoming tour operators (ITOs): initial findings from Eastern Norway
}

\author{
Xiang Ying $M \mathrm{Me}^{1 *}$
}

Received: 22/01/2014 Accepted: 17/05/2014

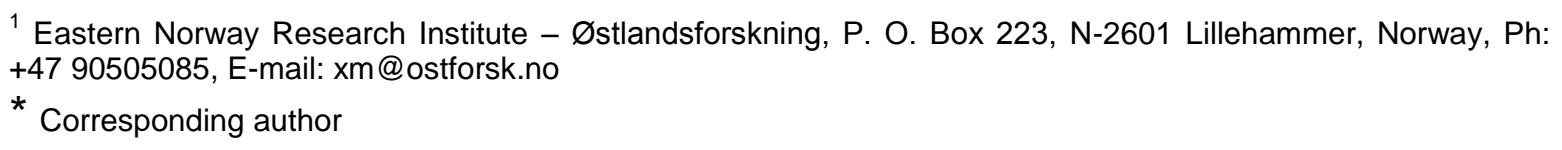

\section{Abstract}

Rapid changes due to technological advancements suggest that tour operators' (TOs) role in the distribution channel needs to be revisited. Based on Eastern Norway, a destination which has much growth potentials, TOs' traditional role may be still useful due to the fragmented tourism industry. However, TOs' general roles as intermediaries are not appreciated and understood by many industry operators. Focusing the discussion on incoming tour operators (ITOs), such operators can no longer solely survive by concentrating on its traditional customer base. In order to thrive in the increasingly competitive environment, ITOs must now seek new customer bases and redefine their role and "place" in the distribution channel.

(c) 2014 International University College. All rights reserved

Keywords: incoming tour operators; tour operators; distribution channel; destination development; Eastern Norway.

Citation: Mei, X. (2014). Revisiting the role of incoming tour operators (ITOs): initial findings from Eastern Norway. European Journal of Tourism Research 8, pp. 148-156

\section{Introduction}

It has been argued that tour operators (TOS) play a key role in tourism industry development ranging from extending the tourism season to the growth of relevant destinations. Nevertheless, the nature of TOs and their roles in distribution channels have evolved significantly in the recent years due to technological advancements such as the Internet. Such changes have also undoubtedly amended the structure of the tourism industry itself. Despite such alterations, Kracht and Wang (2010) argue that the changing structure of tourism distribution has not been sufficiently explored recently. This research note seeks to focus on the TOs' roles as the entire complex structure of the tourism distribution channel is beyond the scope of the current study. Numerous studies have devoted their attention to the role of TOs in developing countries (e.g. Erskine \& Meyer, 2011; Gartner \& Bachri, 1994; Jensen, 2009; Vespestad, 2010). Nevertheless, their role in advanced and developed countries, yet not a matured destination such as Norway is less discussed with the exception of Roper, Jensen \& 
Jegervatn (2005) and Rønningen (2010). More importantly, a paucity of literatures has distinctively differentiated incoming tour operators (ITOs) from outgoing tour operators (OTOs) (Cloquet, 2013) in their discussions. This paper explores the roles that ITOs have on tourism development in a destination with advanced economy as well as ITOs changing roles on the basis of data gathered in Eastern Norway. Although the researcher acknowledges that this topic deserves much more attention than what the current paper can offer, it does highlight some areas of focus which should be further explored in future studies.

\section{Literature Review}

\section{The role of TOs}

Over the years, numerous literatures have reviewed the role of TOs in the tourism industry (including Baloglu \& Mangaloglu, 2001; Buhalis, 2008; Campo \& Yagüe, 2008; Gartner \& Bachri, 1994; Medina-Muñoz, MedinaMuñoz, \& Garcia-Falcón, 2003; PenningtonGray, Reisinger, Kim, \& Thapa, 2005; Sigala, 2008). However, as TOs' position in the distribution channel has rapidly evolved, there is a need to revisit their existing roles. At present, the roles of TOs, particularly in advanced destinations are challenged and debated as some regard their presence as unnecessary. This is due to the fact that consumers are becoming more experienced in arranging and managing holidays on their own (Assaf, Barros, \& Dieke, 2011; Harison \& Boonstra, 2008). Moreover, the few studies that have sought to separate the discussion between ITOs and OTOs (Cloquet, 2013; Jensen, 2009) have merely focused on destinations with developing economies. As these "two types" of operators have arguably different customer bases and partners that they have to relate to in a destination, it is necessary to consider their various roles and functions in the distribution channel.

In general, TOs have contributed significantly to the development of tourism industry worldwide with their package tours which have enabled numerous travellers to realise their dream holidays (Čavlek, 2005). Their main role in the tourism industry consists of developing and distributing package holidays and trips by combining services such as accommodation, transport and activities on behalf of suppliers (Fyall \& Wanhill, 2008). Traditionally, TOs have had substantial power in destination development and growth as they act as gatekeepers of information access and flow in addition to functioning as intermediaries by linking producers and consumers (Buhalis, 2008; Gartner \& Bachri, 1994), particular in developing destinations. In addition, they have also had substantial influence on travellers' purchase decision process (UNWTO, 1977). For larger TOs in particular, they have the ability and power to enlarge their market share and volume through providing inexpensively priced holiday packages (Buhalis, 2008), hence, making it worthwhile for consumers to book their holidays through TOs.

While TOs have been regarded as important global players in the tourism industry, the heightened technological changes have contributed to ruinous competition between various key players (Assaf et al., 2011; Weiermair, 2004). The development of Information Communication Technologies (ICTs) such as the Internet has revolutionised information access and flow. As a result, TOs' role in the tourism distribution system has arguably changed the most. Mulec and Wise (2012) state nevertheless that they still maintain a significant role when comes to destinations that are in the early stages of tourism development or have not fully reached its tourism potentials. In addition, it can be argued that in destinations where the tourism industry is fragmented by consisting of many small businesses; TOs have the ability to reach markets that such businesses are not able to with their existing resources. Subsequently, small businesses may arguably depend entirely on TOs for visibility in the marketplace as well as to establish linkage and dialogue with consumers (Buhalis, 1994). For these reasons, TOs may still play a crucial part in the formation of new markets and in terms of launching new tourism products (Vespestad, 2010).

In regards to ITOs, a recent study suggest that ITO can be defined as enterprises that export local tourism products through sales and marketing overseas that result in foreign guests travelling to the countries where such products 
are located (Heyerdahl Refsum, 2013). Vespestad (2010) states, that ITOs' influence on markets is not substantial within the literature, despite their position as promoters of destination and tourism products. Existing studies that devote their attention to ITOs have however discussed their roles primary in regards to destinations with developing economies (Cloquet, 2013; Jensen, 2009). Generally, ITOs are dependent on their ability to maintain relationships with local tourism operators as well as OTOs (Cloquet, 2013; March, 2000; Pearce, 2007). On the other hand, OTOs who purchase packages and services through ITOs are mostly concerned with their end customers, the tourists. All these types of business relationships will determine their role and "place" in the distribution channel. Since both ITOs and OTOs are dependent on such business relationships, it is therefore critical for them to select the right partners (Cloquet, 2013). Failure in maintaining these relationships may result in TOs seeking partnerships with operators in other destinations instead. More importantly, this may also impact the tourists' experiences of the destination or region. The following section discusses TOs and their challenges in Eastern Norway.

\section{TOs and the Eastern Norway case}

The role of TOs in the Norwegian tourism industry has been much debated in the recent years. It has been suggested that the number of travellers who use the services of TOs is generally declining (Bergsagel, 2013). The TO sector in Norway is facing some significant challenges both in terms of ITOs and OTOs. In the case of Eastern Norway, ITOs typically arrange holiday packages for OTOs on a business-to-business (B2B) basis. TOs have generally two types of customer bases consisting of foreign group travellers (FGT), which are usually large motorcoach tour groups as well as foreign individual travellers (FIT). The similarity is that both groups rely on TOs to develop and package their holidays. TOs changing role is notable in the Inland region in Eastern Norway as they may have lost their role as intermediaries during the summer season. This is attributed by a declining number of motorcoach tour groups which have been, and still are, one of its significant markets. The region is facing two key challenges. Firstly, there is a decline in summer tourist traffic (Statistics Norway, 2013) despite the numerous tourism attractions that are actively promoted by both private and public actors and organisations; and secondly the fragmented nature of the tourism industry in the Inland (The Research Council of Norway, 2012). In addition, the region is relatively unknown as a tourism destination when compared with other typical Norwegian destinations and attractions such as the North and the fjords.

\section{Methodology}

This study is based on a qualitative approach which is suitable for topics and themes which have not been previously explored in greater extent (Myers, 2009). Although there is no lack of literature on TOs, many existing studies have not distinguished ITOs and OTOs as discussed. As this research note serves as a preliminary study to enlighten the issues regarding the current challenges, the results are initial findings based on in-depth interviews with seven Norwegian ITOs in Eastern Norway and four foreign OTOs in four other countries based on the main inbound tourist markets in the region. These include Sweden, Denmark, the Nederland's and Germany. Interview guides were designed as open-ended and semi-structured in order to allow respondents to freely express their opinions. The questions were developed based on existing literature aimed at investigating ITOs current roles and challenges as well as their perception of the region. Respondents were also able to raise topics and themes which they found relevant. Anonymity and confidentiality were also guaranteed by the researcher. The interviews were gathered based on personal interviews with all Norwegian ITOs and telephone interviews with OTOs as this was a more time efficient manner.

TOs were selected based on their product base and relevance to the region. The main criterion was that they had to be familiar with the region by offering tourism products within the region. Web searches were conducted to establish such in addition to information provided by Innovation Norway - Norway's national tourism organisation, containing lists of foreign OTOs 
that offer Norwegian tourism products and destinations. While foreign OTOs' role in particular is not the main focus of this study, their perceptions were also important to include as tourism and destination development would require a sound partnership between ITOs and OTOs (Cloquet, 2013). In addition, despite their various roles, ITOs and OTOs may also have some overlapping roles in the distribution channel. As for Eastern Norway, Norwegian ITOs and foreign OTOs in a partnership would be working towards the same group of enduser and consumers - the inbound tourists to the region. ITOs and OTOs' statements are reported as $\mathrm{I}$ and $\mathrm{O \#}$ in the findings respectively.

\section{Result and Discussion}

Lack of understanding of ITOs

In regards to the current study, respondents clearly expressed that there is a lack of appreciation of ITOs' role in the distribution channel.

There is a lack of understanding of what an ITO does and how important that link is. We have a huge job. A huge one [14].

I really feel like the operators don't understand and appreciate our role in this [tourism industry]. Take this as an example, when we want to book 100 rooms, the price that they give us is the same as they would give to a private person looking to book 10 rooms. This is very frustrating as it undermines our job and role [12].

As discussed, ITOs are dependent on establishing and maintaining relationship not only with OTOs but also with local tourism suppliers (March, 2000; Pearce, 2007). The current study suggests that such relationship proves to be difficult to maintain and establish when ITOs' presence is not appreciated or understood by the market.

I know that incoming operators traditionally here in Norway is struggling to find their place. And I think that the government maybe is more interested in helping foreign tour
operators...maybe [I6].

Such invisibility in the market contributes to undermine ITOs role in the distribution channel. As many tourism destinations, the tourism industry in Inland region in Eastern Norway is fragmented consisting of many small businesses. Thus, they would arguably need TOs to reach certain markets (Buhalis, 1994).

ITOs' as key information sources

Respondents also argued that the materials that they choose to provide on their websites will impact the entire region:

50 percent of the people who visit our website don't book our trips. They only come for the information, then they use the same route and travel by themselves. This means that tourism actors must realise that they are not only getting the tourism traffic directly from us. They also get visitors coming to them because we promote this route and attractions on our website. If we are not here or even take down this product from our website, they will notice the difference in traffic! [I5].

Certainly, in the age of ICTs and the Internet, consumers can obtain information about destinations and attractions from various sources than TOs. However, travellers are often overwhelmed by the information available online and often times are not able to obtain what they intend to find (Pan \& Fesenmaier, 2006). As such, it can be claimed that TOs may provide information in a more organised and time saving manner. This argument should nevertheless be further verified in a future study. In addition, Kracht and Wang (2010) argue that advancement of ICTs has not necessarily reduced the number of intermediaries in the distribution channel, but rather resulted in an increasingly complex array of intermediaries. Such complexity contributes to confuse the consumers in their information search process.

Moreover, in a recent study by Mulec and Wise (2012), the authors state that for destinations that are relatively unknown to the international 
market, TOs play a key role in generating further awareness. In regards to Eastern Norway, both ITOs and OTOs may play significant roles in contributing to such awareness which is important for destination growth and development (Zhong, Deng, \& Xiang, 2008). As noted by an ITO,

We produce the trips, we have webpages, we pay for ads, and when you advertise something, it's not just for one operator, the hotel or whatever. You advertise the entire region [15].

Additionally, if TOs are assumed to acts as gatekeepers of information access and flow (Buhalis, 2000; Gartner \& Bachri, 1994), ITOs that have a negative perception towards a destination or region would likely exclude the destination from their marketing efforts and programs. This may have a significant impact on destinations and regions as discussed in the following section.

\section{The impact of ITOs' perceptions}

As TOs in general may play a crucial role in imparting knowledge of destinations and tourism products to potential consumers (Vespestad, 2010), their perception towards a destination will to some extent also impact how potential consumer will perceive a destination. This is particularly challenging in situations where OTOs purchase tourism products and services from ITOs. ITOs, like any other businesses strive and compete for customers and profit. Such competitive nature is even more prominent at present (Assaf et al., 2011). Therefore, they have the power to select which attractions and intangible qualities to highlight when they market and promote the destinations (Whipple \& Thach, 1988). In such sense, it can be argued that ITOs as intermediaries have substantial influence on destination growth and development. As stated,

At the end of the day, we have to put up things that are easiest to sell. I can't afford to put things up on our website and our brochures if they don't sell! I have pressures from both ends [I3].

It is also assumed that ITOs would have great knowledge of the relevant foreign markets and many respondents suggest that they have extensive local knowledge of the region which is crucial and valued by OTOs.

I would think that they [local suppliers] want us because it is easier to speak to a Norwegian partner. We have a lot of market knowledge on the various markets [I7].

Such extensive knowledge and perceptions of the region are important when comes to marketing and promoting potential local tourism products and destinations to the tourists.

\section{ITOs' key challenges}

Nevertheless, it is evident from this study that ITOs are facing some challenging issues. Based on responses from OTOs, respondents expressed that they wish to purchase products and packages directly from local operators and suppliers in the region rather than going to local ITOs. Much of this is contributed by limiting costs which is more prominent in a high-cost destination such as Norway. Although some foreign OTOs are already doing so, the result suggests that there is a tendency for other smaller foreign OTOs to follow the same direction. Such development may provide additional challenges for local ITOs by further undermining its role in the distribution channel.

We are purchases our products from ITOs at the moment. I, kind of, wish that the operators would contact us or even maybe Visit Lillehammer. Maybe they can put a package together for us instead [03].

Another recent finding also suggests that a majority of ITOs in Norway cannot survive by only providing their services as ITOs. As a response, they are increasingly extending their services to include MICE, cruise and incentive travels (Heyerdahl Refsum, 2013). This corresponds with the current study.

We cannot survive on only incoming anymore. We have started to operate as OTOs now. I feel like that the trend is a decrease of incoming individual tourists internationally [I3]. 
On the other hand, despite the overall role of TOs being challenged, many respondents indicated that certain markets are still mostly dependent on TOs in general and thereby ITOs.

The European market is much more independent. They do a lot themselves without TOs. It is harder for Asian groups for instance. China for instance will use TOs for quite a while I think [I7].

With the Internet nowadays, it's very easy to build your own package. But I'm not too concerned about it now. At least for us, most of our customers are maybe 60 years above and a lot of them don't have computers. But I see more and more people arrange their own holidays [O1]

Based on this study, it is certain that TOs and ITOs in particular have challenging roles as intermediaries in the distribution channel. Figure 1 provides an illustration of the TO structure in the Norwegian market based on the current findings. This study does not suggest that individual travellers will only rely on information from the TOs' website as their sole information source about a certain destination or region. It proposes that although tourists may not book with the TOs directly, the information that TOs choose to promote and share on their website may have a certain degree of influencing factor on travellers who visit such websites for information search purposes. The extent to which such phenomenon is evident and in which degree are topics that need to be explored in future studies.

\section{Concluding remarks and future studies}

Evidently, different markets will have various levels of needs in terms of TOs. Hence, their role in tourism development and growth will also vary according to regions and visitors. The current trends suggest that while they may still maintain a strong role in the distribution channel in some parts of the world, such importance is gradually diminishing in other markets (Assaf et al, 2011). In these markets as indicated in the present study, both ITOs and OTOs can no longer rely on their traditional roles in the increasingly competitive industry.

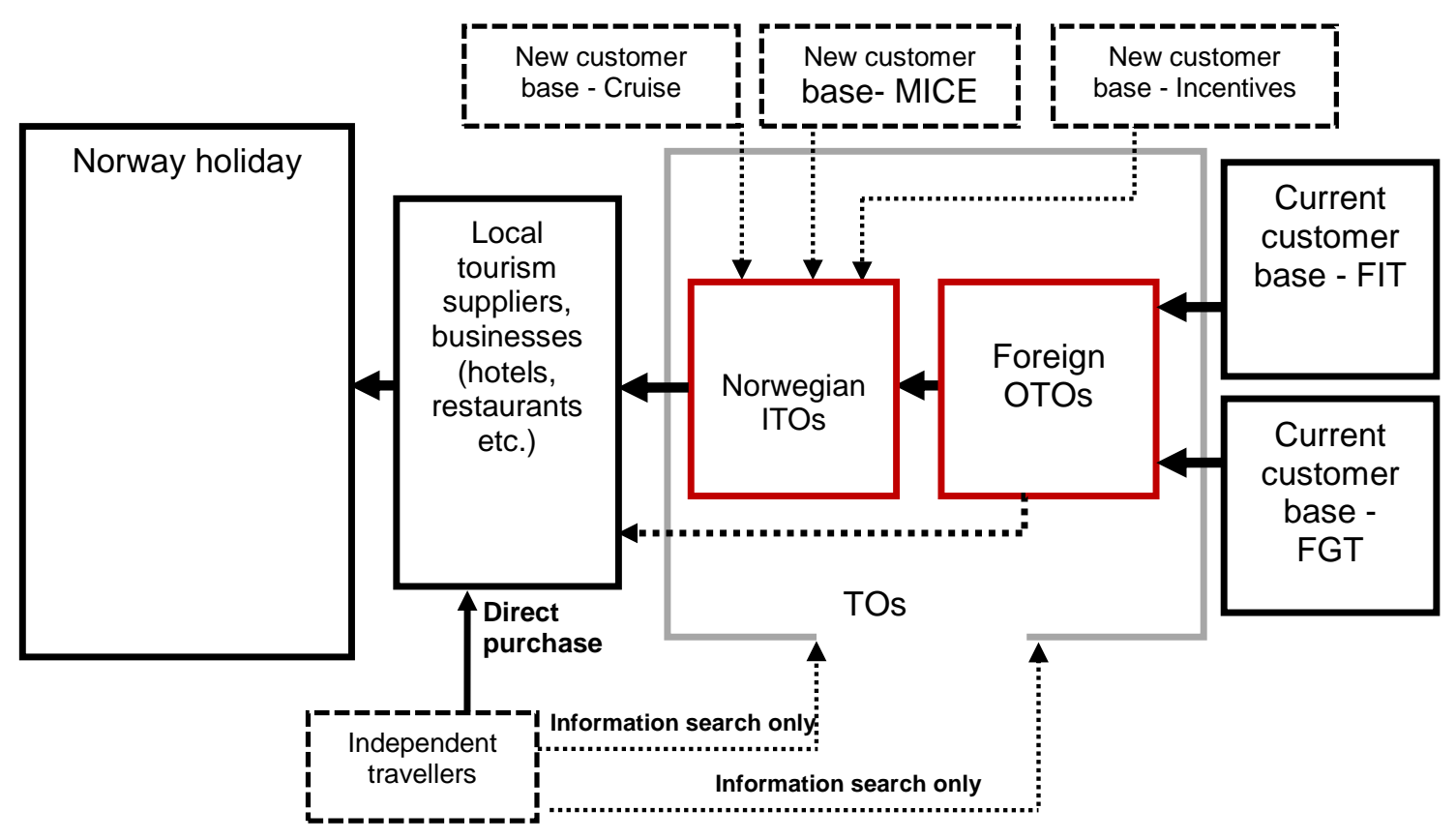

Figure 1. The structure of TO in the Norwegian market 
Although not serving as a complete surprise, the present study has further verified the challenges that ITOs and thereby TOs in general are facing in the tourism industry. In addition, this paper has attempted to separate ITOs and OTOs in the discussion as few previous studies have distinctively acknowledged their different roles. It is crucial to recognise ITOs and OTOs as two separate entities with various roles and with various relationships to maintain and foster in the distribution channel. On the other hand, although ITOs and OTOs have roles that vary in the distribution channel, it can be argued that they are still somewhat dependent on each other at present.

Another finding of this study indicates that in order for ITOs to survive and thrive; they have to possibly change their traditional business model and structure by venturing into new markets and customer bases. Similar challenges may also be present among TOs in general. As this is a case study limited to Eastern Norway, different situation may exist in a different destination or region as well as a different segment. Nevertheless, as the changing role of TOs in general is evident in the global tourism industry, the finding of this study may be applied to other comparable destinations.

Certainly, in order to comprehensive explore the topic, there is a need to obtain data and points of view of other relevant players including Destination Management Organisation (DMOs), government officials and national tourism organisations such as Innovation Norway as well as the tourism operators and more importantly the consumers - the tourists. It is however reasonable to suggest that the presence of TOs in advanced and developed economies is still needed, particularly in destinations that are fragmented and relatively unknown to the international market. Although such destinations and regions are not immune to the challenges faced by TOs in general, both ITOs and OTOs are still playing significant roles in the tourism industry and its future development in many destinations at present.

\section{Acknowledgement}

The research presented in this study is a part of the project "Trends in tourism in the Inland" in collaboration with Lillehammer University College and Norwegian Institute for Nature Research, partially financed by Regional Research Funds in Norway.

\section{References}

Assaf, A. G., Barros, C. P., \& Dieke, P. U. C. (2011). Portuguise tour operators: A fight for survival. Journal of Air Transport Management, 17(3), 155-157.

Baloglu, S., \& Mangaloglu, M. (2001). Tourism destination images of Turkey, Egypt, Greece, and Italy as perceived by USbased tour operators and travel agents. Tourism Management, 22(1), 1-9.

Bergsagel, I. (2013). Det å reise har blitt upersonlig og banalt.URL: http://reise.aftenposten.no/reise/--Det-areise-har-blitt-upersonlig-og-banalt48509.html\#.UrgelLQkzSA Access on 3 September, 2013

Buhalis, D. (1994). Information and telecommunications technologies upon tourism distribution channels: strategic implications for small and medium sized tourism enterprises in the contemporary business environment. In A. Seaton (Ed.), Tourism: The State of the Art (254275). London: John Wiley \& Sons.

Buhalis, D. (2000). Marketing the competitive destination of the future. Tourism Management, 21(1), 97-116.

Buhalis, D. (2008). Relationships in the distribution channel of tourism. International Journal of Hospitality \& Tourism Administration, 1(1), 113-139.

Campo, S., \& Yagüe, M. J. (2008). Tourist Loyalty to Tour Operator: Effects of Price Promotions and Tourist Effort. Journal of Travel Research, 46(3), 318-326. doi: $10.1177 / 0047287507303975$

Čavlek, N. (2005). The impact of tour operators on tourism development: a sequence of events. In J. Aramberri \& R. Butler (Eds.), Tourism Development: Issues for a Vulnerable Industry (174-192). Clevedon: Channel View Publications.

Cloquet, I. (2013). Looking into the overlooked: incoming tour operators and early 
tourism development in Gabon. Current Issues in Tourism, 16(7-8), 647-663.

Erskine, L. M., \& Meyer, D. (2011). Influenced and influential: the role of tour operators and development organisations in tourism and poverty reduction in Ecuador. Journal of Sustainable Tourism, 20(3), 339-357. doi: 10.1080/09669582.2011.630470

Fyall, A., \& Wanhill, S. (2008). Intermediaries. In C. Cooper, J. Fletcher, A. Fyall, D. Gilbert \& S. Wanhill (Eds.), Tourism: Principles and Practice. Harlow: Prentice Hall, 420-459.

Gartner, W. C., \& Bachri, T. (1994). Tour operators' role in the tourism distribution system: an Indonesian case study Journal of International Consumer Marketing, 6(3/4), 161-179.

Harison, E., \& Boonstra, A. (2008). Reaching new altitudes in e-commerce. Assessing the performance of airline websites. Journal of Air Transport Management, 14(2), 92-98.

Heyerdahl Refsum. (2013). Incoming 2013: Heyerdahl Refsum AS.

Jensen, $\varnothing$. (2009). The activation of local service suppliers by incoming tour operators in a "developing" destination the case of Madagascar. Current Issues in Tourism, 12(2), 133-163.

Kracht, J., \& Wang, Y. (2010). Examining the tourism distribution channel: evolution and transformation. International Journal of Contemporary Hospitality Management, 22(5), 736-757.

March, R. (2000). Byer decision-making behaviour in international tourism channelse. International Journal of Hospitality \& Tourism Administration, 1(1), 11-25.

Medina-Muñoz, R. D., Medina-Muñoz, D. R., \& Garcia-Falcón, J. M. (2003). Understanding European tour operators' control on accommodation companies: an empirical evidence. Tourism Management, 24(2), 135-147.

Mulec, I., \& Wise, N. (2012). Foreign tour operators and travel agents knowledge of a potential tourism destination: the Vojvodina region of Serbia. Managing Global Transitions: International Research Journal, 10(2), 171-187.
Myers, M. D. (2009). Qualitative Research in Business Management. Wiltshire: Sage Publications.

Pan, B., \& Fesenmaier, D. R. (2006). Online Information Search: Vacation Planning Process. Annals of Tourism Research, 33(3), 809-832.

Pearce, D. G. (2007). Supplier selection in the New Zealand inbound tourism industry. Journal of Travel and Tourism Marketing, 23(1), 57-69.

Pennington-Gray, L., Reisinger, Y., Kim, J. E., \& Thapa, B. (2005). Do US tour operators' brochures educate the tourist on culturally responsible behaviours? A case study for Kenya. Journal of Vacation Marketing, 11(3), 265-284.

Roper, A., Jensen, Ø., \& Jegervatn, R. H. (2005). The Dynamics of the Norwegian Package Tour Industry. Scandinavian Journal of Hospitality and Tourism, 5(3), 193-211.

Rønningen, M. (2010). Innovative processes in a nature-based tourism case Current Issues in Tourism, 10(3), 190-206.

Sigala, M. (2008). A supply chain management approach for investigating the role of tour operators on sustainable tourism: the case of TUI. Journal of Cleaner Production, 16(15), 1589-1599.

Statistics Norway. (2013). Overnattinger. URL: http://www.ssb.no/overnatting. Access on 08 November 2013

The Research Council of Norway. (2012). Forskningsprosjektet VRI Innlandet 2011-2013. URL: http://www. forskningsradet.no/prognett-vri/

Forskerfakta 201113/Satellite?blobcol=u rldata\&blobheader=application\%2Fpdf\&b lobheadername $1=$ Content-Disposition $\% 3 A \&$ blobheadervalue $1=+$ attachment $\%$ 3B+filename\%3DInnlandet-

Forskningsprosjekt-A4lores.pdf\&blobkey =id\&blobtable=MungoBlobs\&blobwhere= $1274497754384 \&$ ssbinary=true. Access on 20 November, 2013

UNWTO. (1977). Factors influencing travel demand and leading to the redistribution of tourist movements. Madrid: UNWTO.

Vespestad, M. K. (2010). Tour operators' insight into the Russian nature-based experience market. European Journal of Tourism Research, 3(1), 38-53. 
Revisiting the role of incoming tour operators (ITOs): initial findings from Eastern Norway.

Weiermair, K. (2004). Product improvement or innovation: What is the key to success in tourism? OECD. URL: https://www1.oecd.org/cfe/tourism/34267 947.pdf DATE OF ACCESS

Whipple, W., \& Thach, V. (1988). Group tour management: does good service produce satisfied customers? Journal of Travel Research, 27(2), 16-21.

Zhong, L., Deng, J., \& Xiang, B. (2008). Tourism development and the tourism area life-cycle model: A case study of Zhangjiajie National Forest Park, China. Tourism Management, 29(5), 841-856. 